\title{
CHEMOMETRIC ESTIMATION OF CAPTURED FARFANTEPENAEUS NOTIALIS, PÉREZ-FARFANTE 1967 (CRUSTACEA: PENAEIDAE)
}

\author{
Rasheed Olatunji Moruf ${ }^{1 凶}$, Mosunmola Florence Akinwunmi², \\ Aderonke Omolara Lawal-Are ${ }^{2}$ \\ ${ }^{1}$ Department of Fisheries and Aquaculture, Bayero University, Kano \\ Kano, Kano State, Nigeria \\ ${ }^{2}$ Department of Marine Sciences, University of Lagos \\ Akoka, Lagos State, Nigeria
}

\begin{abstract}
Background. Chemometrics can be used to analyze a wide range of food products for authentication, quality control, differentiation and the determination of nutrition quality. Owing to the scarcity of studies relating to the intrinsic physico-chemical characteristics of penaeid shrimps caught on the Nigerian coast, the aim of this research was to estimate the energy-supplying nutrients, mineral elements and functional characteristics of Farfantepenaeus notialis from the Lagos Lagoon.

Materials and methods. The proximate composition was determined using the AOAC method while the energy-providing nutrients were multiplied by the Atwater factors. The samples were digested in $\mathrm{HNO}_{3} / \mathrm{HCl}$ for mineral determination and the functional properties were estimated using optical measurements.

Results. Higher concentrations of moisture, crude protein, crude fat, and carbohydrate were recorded in the flesh while crude fibre and total ash were higher in the exoskeleton samples. The flesh had higher total

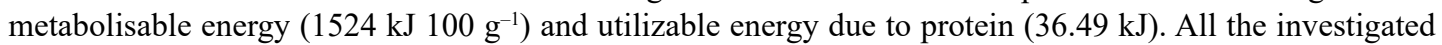
minerals $(\mathrm{Ca}, \mathrm{Mg}, \mathrm{K}, \mathrm{P}$ and $\mathrm{Na}$ ) were more concentrated in the exoskeleton. In both samples, $\mathrm{Na} / \mathrm{K}$ and $\mathrm{Na} /$ $\mathrm{Mg}$ ratios were within acceptable ideal ranges of 1.4-3.4 and 2-6, respectively. All values of the MSI (calculated) were lower than their comparative standard index values, having positive contrasts in both exoskeleton and flesh samples. The exoskeleton sample had better functional properties, but the flesh sample was higher in swelling strength.

Conclusion. In addition to good flesh quality, F. notialis contains considerable amounts of energy-providing nutrients. As the content of fibre is very low, F. notialis may be ideal as a weaning food for children.
\end{abstract}

Keywords: Shrimp, nutritional quality, mineral index, Lagos Atlantic Ocean

\section{INTRODUCTION}

Important shellfish such as shrimp, prawns, crayfish, lobster, and crab constitute one of the major sources of nutritious food for humans, providing an important amount of dietary protein and lipids in many countries (Lawal-Are et al., 2021). Traditionally, shrimps have become one of the most highly traded seafood resources. They are recognised as an important commodity in the international fishery trade, and there is evidence of a rise in the consumption of crustaceans worldwide (Manan and Ikhwanuddin, 2020). Marine shrimps dominate the production of typically farmed crustaceans in coastal aquaculture and are an important 
source of foreign exchange earnings for a number of developing countries, with catches reaching new peaks of over 336,000 tons in 2018 (FAO, 2020). Penaeid shrimps have been described as one of the most valuable economic tools in the world's crustacean fishery and aquaculture sector (Manan and Ikhwanuddin, 2020). Farfantepenaeus notialis is a species of penaeid shrimp caught in the marine and brackish waters of Southern Nigeria. The adult pink shrimp stock off the coast of Lagos has been confirmed to be replenished by the juveniles and sub-adults of the adjacent Lagos Lagoon and its creeks with its nursery ground off the Lagos Coast in the Lagos Lagoon (Akinjogunla and Moruf, 2018).

Penaeid shrimps are a popular proteinase seafood with no cultural restrictions in the diet regimens of most consumers in Nigeria. Crustaceans such as shrimps absorb and amass omega ${ }^{-3}$ fatty acids through food chain algae and phytoplankton, the key makers of omega ${ }^{-3}$ unsaturated fatty acids (Mili et al., 2013; Moruf and Akinjogunla, 2019). Shrimps also contain many dietary minerals, such as calcium, iron, magnesium, sodium, etc., in addition to providing good quality proteins and lipids, which are beneficial in playing an important role in the maintenance of physiological and biochemical activities in humans (Banu et al., 2016).

The biochemical parameters of wild crustaceans are highly affected by the environmental factors that decide the availability of nutrients, while artificial diet feeding determines the quality of nutrients and the composition of flesh in cultured crustaceans (Akinwunmi, 2016; Anwarul et al., 2017). There are some recent studies that support crustacean consumption in contrast to its allegedly elevated cholesterol or allergenic reactions (Afolayan et al., 2020; Lawal-Are et al., 2021; Moruf and Lawal-Are, 2019; Moruf et al., 2019; Oluwole et al., 2020). Information on the quality and intrinsic physico-chemical characteristics of penaeid shrimps, however, is scarce, especially on those living on the Lagos coast of Nigeria. Therefore, the aim of the study was to estimate the biochemical indices, proportion of energy due to nutrients, mineral ratios, Mineral Safety Index (MSI), and functional characteristics of the exoskeleton and flesh of $F$. notialis from the Lagos Lagoon in Nigeria. This study will provide some basic information to help evaluate the application for shrimp protein isolates in food products.

\section{MATERIALS AND METHODS}

\section{Study area}

The Lagos Lagoon, which is one of Nigeria's main lagoon ecosystems, is a coastal lagoon that promotes the well-being of resident species and coastal populations by providing a source of food and employment (Nwabueze et al., 2020). The lagoon complex is a continuous system located along the coast of Nigeria from the border of the Republic of Benin to the Niger Delta. The sampling stations (Fig. 1) are within the western part of the Lagos Lagoon, $3^{\circ} 10^{\prime} \mathrm{E}$ and $3^{\circ} 45^{\prime} \mathrm{E}$, and $6^{\circ} 15^{\prime} \mathrm{N}$ and $6^{\circ} 36^{\prime} \mathrm{N}$ (Moruf and Lawal-Are, 2017).

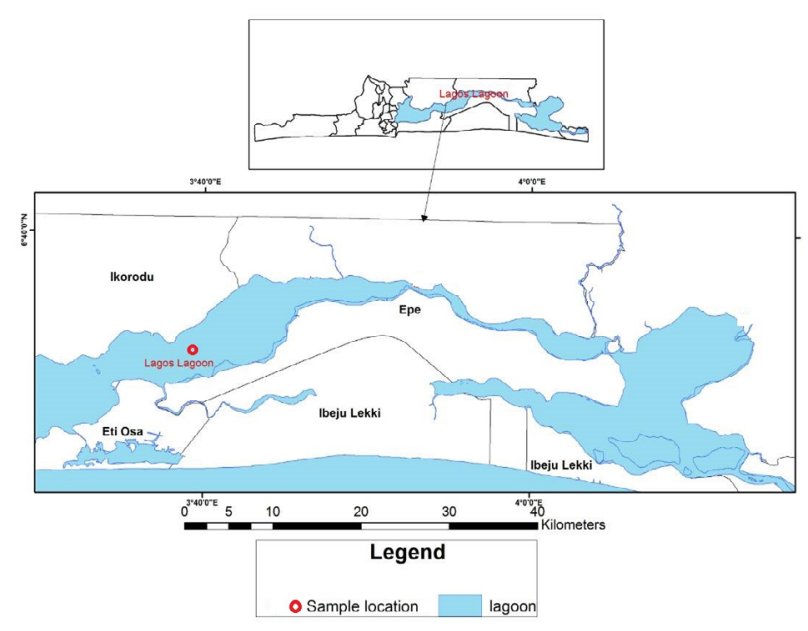

Fig. 1. Map of Lagos Lagoon showing the sampling site (adapted from Akinwunmi and Lawal-Are, 2019)

\section{Sample collection}

The harvested samples of $F$. notialis were obtained between May and October 2019 from the local landing of the Lagos Lagoon at Makoko jetty in Lagos State, Nigeria. The shrimps were immediately transported in an ice-chest and subsequently preserved in a deep freezer at a temperature of $-20^{\circ} \mathrm{C}$ in the laboratory for chemical analysis. Thirty (30) individuals from each catch (180 samples in total) of identical physical conditions and size $(9.2 \pm 4.22 \mathrm{~cm}$ and $20.7 \pm 5.12 \mathrm{~g})$ were randomly chosen as test subjects. Within the error ranges of $\pm 0.01 \mathrm{~g}$ and $\pm 0.01 \mathrm{~cm}$, the respective weight and length of the shrimp were accurately measured. 


\section{Sample analysis}

The samples were thawed for one hour after removal from the freezer and divided into fillet extract and exoskeleton. The different components were dried and homogenised at $105^{\circ} \mathrm{C}$. To evaluate the crude protein, the Micro-Kjeldahl Method was adopted. The crude fat was extracted using the Soxhlet extraction apparatus with a chloroform/methanol $(2: 1 \mathrm{v} / \mathrm{v})$ mixture. The determination of moisture, ash and crude fibre preceded the method of AOAC (2006) whilst carbohydrate was determined by difference. Multiplying the crude fat, protein, and carbohydrate by the Atwater factors $37 / 9,17 / 4$ and $17 / 4$ respectively, the calorific values were estimated. The samples were digested in $\mathrm{HNO}_{3} / \mathrm{HCl}$ for mineral determination. Some elements $(\mathrm{Ca}, \mathrm{P}, \mathrm{Mg}, \mathrm{Na}$ and $\mathrm{K}$ ) were then calculated by the Buck Scientific 210 GVP model of the Varian Spectra Atomic Absorption Spectrophotometer, following the procedure of Santoso et al. (2006). Mineral ratios and MSI were calculated according to Watts (2010) and Hatcock (1985) respectively.

$$
\text { MSI }=[\text { TMSI (standard) } / \mathrm{RAI}] \cdot R_{r}
$$

where:

MSI - mineral safety index,

TMSI - tabulated MSI,

RAI - recommended adult intake,

$R_{r} \quad-$ research results.

Water absorption capacity (WAC) and oil absorption capacity $(\mathrm{OAC})$ were determined using the method described by Brishti et al. (2017). Approximately $0.25 \mathrm{~g}$ of exoskeleton and flesh samples were separately mixed with $50 \mathrm{~mL}$ of distilled water or oil in a pre-weighed centrifuge tube for 30 secs. Then the samples were placed at $25^{\circ} \mathrm{C}$ for $15 \mathrm{~min}$ and centrifuged at $3000 \mathrm{rpm}$ for $15 \mathrm{~min}$. The supernatant was decanted, and the centrifuge tubes + precipitate were re-weighed. The WAC and OAC were calculated using equation 2 :

$$
\mathrm{WAC} \text { or } \mathrm{OAC}=\frac{W_{1}}{W_{2}}
$$

where:

$W_{1}$ - weight of the dry sample, g,

$W_{2}$ - weight of precipitate + centrifuge tube, g.
To evaluate the emulsion stability, the updated method stated by Souissi et al. (2007) was used. The foam formation and the foam stability were determined using optical measurements. The foams were produced with a homogenizer for $2 \mathrm{~min}$ at 17,500 $\mathrm{rpm}$, in $3 \mathrm{~mL}$ of solution $(50 \mathrm{mM}$ Tris- $\mathrm{HCl}-0.5 \mathrm{M}$ $\mathrm{NaCl}, \mathrm{pH} 7.5$ ), which contained $1.5 \%$ protein. Using a caliper, the initial height of the solution and the foam height were recorded at intervals of $0,2,10,20$ and $30 \mathrm{~min}$. The foaming capacity was expressed as the proportion of foam height at 0 min to solution height. The gel was expressed as swelling power after separating from the supernatant. While the supernatant was placed on a plate with a known weight, it was then dried to a constant weight in an oven. Swelling power was calculated using equation 3 .

$$
\text { Swelling power }=\frac{W_{2}-W_{1}}{W_{0}}
$$

where:

$W_{0}$ - weight of the dry sample, g,

$W_{1}$ - weight of the dry sample + centrifuge tube, $\mathrm{g}$,

$W_{2}$ - weight of gel + centrifuge tube, $\mathrm{g}$.

\section{Statistical data analysis}

The data were subjected to descriptive statistics, and Pearson correlation analysis using SPSS for Windows (version 22.0). The significance of the results (LSD test) at $p<0.05$ was tested by means of a one-way ANOVA.

\section{RESULTS AND DISCUSSION}

\section{Proximate compositional differentiation}

Aquatic animal foods have high quality, highly digestible protein content that is richer in essential amino acids and many peptides relative to terrestrial meat proteins (Khalili and Sampels, 2018). Table 1 presents the proximate composition of the exoskeleton and flesh of the harvested $F$. notialis based on dry matter. Important results in $\mathrm{g} 100 \mathrm{~g}^{-1}$ were as follows: moisture $(15.03$ $\pm 0.63-16.11 \pm 0.51)$ with a CV\% of 4.90 ; protein (49.81 $\pm 0.05-54.52 \pm 0.01)$ with a $6.38 \mathrm{CV} \%$; crude fat $(10.79 \pm 0.01-11.51 \pm 0.12)$ with a $4.57 \mathrm{CV} \%$; total ash $(10.06 \pm 0.5-14.77 \pm 0.2)$ with a $26.83 \mathrm{CV} \%$. Carbohydrate of $6.83 \pm 0.90-7.79 \pm 0.35$ with a $9.29 \mathrm{CV} \%$, 
Moruf, R. O., Akinwunmi, M. F., Lawal-Are, A. O. (2021). Chemometric estimation of captured Farfantepenaeus notialis, Pérez-Farfante 1967 (Crustacea: Penaeidae). Acta Sci. Pol. Technol. Aliment., 20(3), 291-299. http://dx.doi.org/10.17306/J.AFS.2021.0947

Table 1. Proximate composition of Farfantepenaeus notialis based on dry matter

\begin{tabular}{lccrr}
\hline $\begin{array}{c}\text { Parameters } \\
\text { g 100 g- }\end{array}$ & Exoskeleton & Flesh & CV\% & $\% \mathrm{D}$ \\
\hline Moisture & $15.03 \pm 0.63$ & $16.11 \pm 0.51$ & 4.90 & -7.19 \\
Protein & $49.81 \pm 0.05$ & $54.52 \pm 0.01$ & 6.38 & -9.46 \\
Crude fat & $10.79 \pm 0.01$ & $11.51 \pm 0.12$ & 4.57 & -6.67 \\
Crude fibre & $2.4 \pm 0.01$ & $0.01 \pm 0.01$ & 140.25 & 99.58 \\
Total ash & $14.77 \pm 0.2$ & $10.06 \pm 0.5$ & 26.83 & 31.89 \\
Carbohydrate & $6.83 \pm 0.90$ & $7.79 \pm 0.35$ & 9.29 & -14.06 \\
\hline
\end{tabular}

$\mathrm{CV} \%$ - coefficient of variation percentage, $\% \mathrm{D}$ - percentage difference between exoskeleton and flesh.

while crude fibre had the highest level of $\mathrm{CV} \%$ (140.25) with a percentage difference $(\% \mathrm{D})$ of 99.58 . The higher ash content may be due to high levels of chitin and calcium in the exoskeleton sample. The content of protein in this study is generally much higher compared with the protein level recorded by Banu et al. (2016) in five species of penaed shrimp, where Penaeus monodon contained protein of 36.88

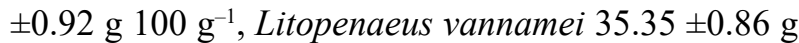

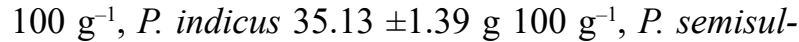

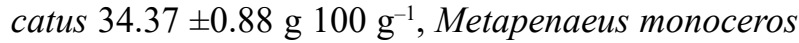

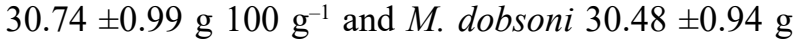
$100 \mathrm{~g}^{-1}$. The same was not observed in the lipid content as the value of $F$. notialis crude fat in the present study

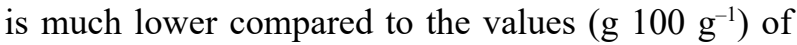
$15.34 \pm 0.75,15.12 \pm 0.68,16.18 \pm 0.84,16.72 \pm 0.78$, $17.14 \pm 0.82$, and $17.45 \pm 0.84$ for P. monodon, L. vannamei, $P$. indicus, $P$. semisulcatus, $M$. monoceros and M. dobsoni, respectively (Banu et al., 2016). The high $\mathrm{CV}$ percentage range in the present study suggests heterogeneous relationships between exoskeleton and flesh proximate compositions of $F$. notialis.

\section{Energy contribution from nutrients}

The percentage energy contribution from nutrients is contained in Table 2. Total energy (metabolisable)

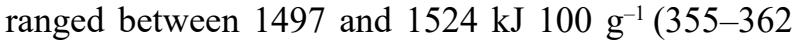
$\left.\mathrm{kcal} 100 \mathrm{~g}^{-1}\right)$. The proportion of energy from protein (PEP) was the highest both in the exoskeleton (56.6\%) and in the flesh sample $(60.8 \%)$. The smallest energy contribution was from carbohydrate $(\mathrm{PEC}=11.1-$ $16.8 \%$ ). Utilizable energy due to protein (UEDP\%) $(60 \%$ of protein energy utilization assumed) was higher in the flesh $(36.49 \mathrm{~kJ})$ than in the exoskeleton $(33.94$ $\mathrm{kJ}$ ) with $5.12 \mathrm{CV} \%$. The trend of energy contribution, $\mathrm{PEP} \%>\mathrm{PEF} \%>\mathrm{PEC} \%$ is comparable to the pattern in the Royal Spiny Lobster, Panulirus regius (Moruf et al., 2021a).

Table 2. Energy value contributed by nutrients in Farfantepenaeus notialis

\begin{tabular}{|c|c|c|c|c|c|c|}
\hline Parameter & Unit & Exoskeleton & Flesh & Mean & SD & $\mathrm{CV} \%$ \\
\hline \multirow[t]{2}{*}{ Total energy } & $\mathrm{kJ} 100 \mathrm{~g}^{-1}$ & 1497 & 1524 & 1510.5 & 19.09 & 1.26 \\
\hline & kcal $100 \mathrm{~g}^{-1}$ & 355 & 362 & 358.5 & 4.95 & 1.38 \\
\hline \multirow{2}{*}{$\begin{array}{l}\text { Proportion of total energy } \\
\text { due to fat }\end{array}$} & $\%\left(\mathrm{~kJ} 100 \mathrm{~g}^{-1}\right)$ & 26.7 (399) & $27.9(426)$ & 27.3 & 0.85 & 3.11 \\
\hline & $\%\left(\right.$ kcal $\left.100 \mathrm{~g}^{-1}\right)$ & $27.4(97)$ & $28.6(104)$ & 28 & 0.85 & 3.03 \\
\hline \multirow{2}{*}{$\begin{array}{l}\text { Proportion of total energy } \\
\text { due to carbohydrate }\end{array}$} & $\%\left(\mathrm{~kJ} 100 \mathrm{~g}^{-1}\right)$ & $16.8(251)$ & $11.2(171)$ & 14 & 3.96 & 28.28 \\
\hline & $\%\left(\mathrm{kcal} 100 \mathrm{~g}^{-1}\right)$ & $16.6(59)$ & $11.1(40)$ & 13.85 & 3.89 & 28.08 \\
\hline \multirow{2}{*}{$\begin{array}{l}\text { Proportion of total energy } \\
\text { due to protein }\end{array}$} & $\%\left(\mathrm{~kJ} 100 \mathrm{~g}^{-1}\right)$ & $56.6(847)$ & $60.8(927)$ & 58.7 & 2.97 & 5.06 \\
\hline & $\%\left(\right.$ kcal $\left.100 \mathrm{~g}^{-1}\right)$ & 56.1 (199) & $60.2(218)$ & 58.15 & 2.9 & 4.99 \\
\hline \multirow{2}{*}{$\begin{array}{l}\text { Utilization of energy value } \\
\text { due to protein }\end{array}$} & $\mathrm{kJ}$ & 33.94 & 36.49 & 35.22 & 1.8 & 5.12 \\
\hline & kcal & 33.67 & 36.15 & 34.91 & 1.75 & 5.02 \\
\hline
\end{tabular}


Moruf, R. O., Akinwunmi, M. F., Lawal-Are, A. O. (2021). Chemometric estimation of captured Farfantepenaeus notialis, Pérez-Farfante 1967 (Crustacea: Penaeidae). Acta Sci. Pol. Technol. Aliment., 20(3), 291-299. http://dx.doi.org/10.17306/J.AFS.2021.0947

Table 3. Mineral content of the exoskeleton and flesh of Farfantepenaeus notialis

\begin{tabular}{lcccc}
\hline $\begin{array}{l}\text { Parameters } \\
\text { mg } 100 \mathrm{~g}^{-1}\end{array}$ & Exoskeleton & Flesh & CV\% & $\% \mathrm{D}$ \\
\hline Calcium & $74.28 \pm 0.31$ & $56.08 \pm 0.55$ & 19.74 & 24.5 \\
Magnesium & $27.36 \pm 0.45$ & $19.93 \pm 0.41$ & 22.22 & 27.16 \\
Potassium & $41.11 \pm 0.23$ & $32.79 \pm 0.11$ & 15.92 & 20.24 \\
Phosphorus & $119.57 \pm 0.81$ & $98.44 \pm 0.15$ & 13.71 & 17.67 \\
Sodium & $57.89 \pm 0.65$ & $43.53 \pm 0.51$ & 20.02 & 24.81 \\
Total & $320.21 \pm 0.36$ & $250.77 \pm 0.92$ & 17.2 & 21.69 \\
\hline
\end{tabular}

\section{Mineral compositional differentiation}

Table 3 presents the mineral contents of the exoskeleton and flesh of $F$. notialis. The total mineral values were $320.21 \pm 0.36 \mathrm{mg} 100 \mathrm{~g}^{-1}$ (exoskeleton) $>250.77$ $\pm 0.92 \mathrm{mg} 100 \mathrm{~g}^{-1}$ (flesh). All the measured minerals were higher in the exoskeleton than in the flesh of $F$. notialis. The minerals decreased in the following order: phosphorus $>$ calcium $>$ sodium $>$ potassium $>$ magnesium, for both the exoskeleton and flesh of $F$. notialis. Differences $(\% \mathrm{D})$ in mineral percentage values ranged from 17.67-27.16 with the least and highest recorded for phosphorus and magnesium, respectively. According to Moruf and Akinjogunla (2018), magnesium is an activator of the enzyme system, which functions in the metabolism of carbohydrates to produce energy. The finding in the present study is consistent with the recorded mineral trend for Squilla aculeata calmani
(Lawal-Are et al., 2018a) and that of the feral gercacinid crab, Cardiosoma armatum (Moruf et al., 2021b). According to Lawal-Are et al. (2018b), a number of factors affect the mineral concentration in shellfish: seasonality, biological variations, food supply, and body parts.

\section{Mineral ratios}

Assessing the interrelationship between nutritional compositions is much more than just estimating the mineral concentrations. Table 4 presents the mineral ratios in the exoskeleton and flesh of $F$. notialis. Na/K and $\mathrm{Na} / \mathrm{Mg}$ were within the appropriate ideal range of 1.4-3.4 and 2-6 respectively in both samples, while other ratios were below the ideal range, as reported in the raw and grilled meat of $C$. amartum (Moruf et al., 2021c). The interaction of sodium and potassium is integral to maintaining healthy blood. According to McDonough et al. (2017), raising the dietary potassium to sodium ratio to the recommended level helps reduce heart and kidney disease.

\section{Mineral safety index}

The MSI of the exoskeleton and flesh of $F$. notialis is found in Table 5. All the calculated MSI values (MSIcv) were lower than the corresponding standard MSI values (MSIsv), resulting in positive differences in the exoskeleton and flesh samples. This is in contrast to mineral $(\mathrm{Ca})$ overloading to the tune of $38.60 \%$, as observed in grilled crabmeat (Moruf et al., 2021c). Calculated MSI < standard MSI means non-overload / non-toxic mineral when the sample is consumed.

Table 4. Mineral ratios in the exoskeleton and flesh of Farfantepenaeus notialis

\begin{tabular}{lccccccc}
\hline \multicolumn{1}{c}{ Parameters } & Ref. balance & $\begin{array}{c}\text { Acceptable } \\
\text { ideal range }\end{array}$ & Exoskeleton & Flesh & Mean & SD & CV\% \\
\hline $\mathrm{Ca} / \mathrm{Mg}$ & 7 & 3 to 11 & 2.71 & 2.81 & 2.76 & 0.07 & 2.53 \\
$\mathrm{Ca} / \mathrm{K}$ & 4.2 & 2.2 to 6.2 & 1.81 & 1.71 & 1.76 & 0.07 & 3.88 \\
$\mathrm{Ca} / \mathrm{P}$ & 2.6 & 1.5 to 3.6 & 0.62 & 0.57 & 0.6 & 0.04 & 6.12 \\
$\mathrm{Na} / \mathrm{K}$ & 2.4 & 1.4 to 3.4 & 1.49 & 1.41 & 1.37 & 0.06 & 4.17 \\
$\mathrm{Na} / \mathrm{Mg}$ & 4 & 2 to 6 & 2.12 & 2.18 & 2.15 & 0.05 & 2.25 \\
{$[\mathrm{~K} /(\mathrm{Ca}+\mathrm{Mg})]$} & 2.2 & & 0.67 & 0.7 & 0.69 & 0.02 & 3.1 \\
\hline
\end{tabular}


Moruf, R. O., Akinwunmi, M. F., Lawal-Are, A. O. (2021). Chemometric estimation of captured Farfantepenaeus notialis, Pérez-Farfante 1967 (Crustacea: Penaeidae). Acta Sci. Pol. Technol. Aliment., 20(3), 291-299. http://dx.doi.org/10.17306/J.AFS.2021.0947

Table 5. Mineral safety index of the exoskeleton and flesh of Farfantepenaeus notialis

\begin{tabular}{|c|c|c|c|c|c|c|c|c|c|c|c|}
\hline \multirow{2}{*}{ Mineral } & \multirow{2}{*}{$\begin{array}{c}\text { RAI } \\
\text { mg }\end{array}$} & \multirow{2}{*}{$\mathrm{MSI}_{\mathrm{sv}}$} & \multicolumn{3}{|c|}{ Exoskeleton } & \multicolumn{3}{|c|}{ Flesh } & \multirow{2}{*}{ Mean } & \multirow{2}{*}{ SD } & \multirow{2}{*}{ CV\% } \\
\hline & & & $\mathrm{MSI}_{\mathrm{cv}}$ & $\mathrm{D}$ & $\% \mathrm{D}$ & $\mathrm{MSI}_{\mathrm{cv}}$ & $\mathrm{D}$ & $\% \mathrm{D}$ & & & \\
\hline $\mathrm{Ca}$ & 1200 & 10 & 0.62 & 9.38 & 93.81 & 0.47 & 9.53 & 95.33 & 0.54 & 0.11 & 19.74 \\
\hline $\mathrm{Mg}$ & 400 & 15 & 1.03 & 13.97 & 93.16 & 0.75 & 14.25 & 95.02 & 0.89 & 0.2 & 22.22 \\
\hline $\mathrm{P}$ & 1200 & 10 & 1 & 9 & 90.04 & 0.82 & 9.18 & 91.8 & 0.91 & 0.12 & 13.71 \\
\hline $\mathrm{Na}$ & 500 & 4.8 & 0.56 & 4.24 & 88.42 & 0.42 & 4.38 & 91.29 & 0.49 & 0.1 & 20.02 \\
\hline
\end{tabular}

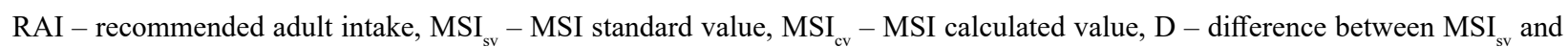
$\mathrm{MSI}_{\mathrm{cv}} \% \mathrm{D}$ - percentage difference, $\mathrm{SD}$ - standard deviation, $\mathrm{CV} \%$ - coefficient of variation percentage, no MSI standard for K.

\section{Relationship between proximate and mineral compositions}

Some major associations between the analysed proximate and mineral parameters were shown by the relationship matrix for the exoskeleton (Table 6) and flesh samples (Table 7). In the exoskeleton matrix, only $\mathrm{P}$ and $\mathrm{Na}$ demonstrated nearly perfect positive relationships with the proximate parameters (with the exception of crude fibre and carbohydrate). In the flesh sample, only crude fibre showed positive relationships with all minerals, while other proximate parameters showed negative relationships with all the minerals.
This finding is comparable to the report on the macroand micro-nutrients of the shell and flesh of Callinectes amnicola from Southwest Nigeria (Moruf et al., 2019). In the present study, the positive relationship in the nutritional quality indicates that changes in proximate composition are associated with changes in the mineral contents of the shrimp. However, correlation does not mean that the changes in proximate composition actually cause the changes in the mineral content.

Table 6. Correlation coefficient among the proximate and mineral compositions of the exoskeleton of Farfantepenaeus notialis

\begin{tabular}{|c|c|c|c|c|c|c|c|c|c|c|c|}
\hline & Moisture & Protein & Fat & Fibre & Ash & $\mathrm{CHO}$ & $\mathrm{Ca}$ & $\mathrm{Mg}$ & $\mathrm{K}$ & $\mathrm{P}$ & $\mathrm{Na}$ \\
\hline Moisture & 1 & & & & & & & & & & \\
\hline Protein & 0.99 & 1 & & & & & & & & & \\
\hline Fat & 0.99 & 0.99 & 1 & & & & & & & & \\
\hline Fibre & -0.67 & -0.72 & -0.76 & 1 & & & & & & & \\
\hline Ash & 0.99 & 0.98 & 0.97 & -0.57 & 1 & & & & & & \\
\hline NFE & -0.76 & -0.80 & -0.83 & 0.99 & -0.67 & 1 & & & & & \\
\hline $\mathrm{Ca}$ & -0.49 & -0.43 & -0.38 & -0.31 & -0.60 & -0.19 & 1 & & & & \\
\hline $\mathrm{Mg}$ & -0.91 & -0.88 & -0.85 & 0.30 & -0.95 & 0.42 & 0.81 & 1 & & & \\
\hline K & -0.54 & -0.48 & -0.43 & -0.27 & -0.64 & -0.14 & 0.99 & 0.84 & 1 & & \\
\hline $\mathrm{P}$ & 0.99 & 0.99 & 0.98 & -0.64 & 0.99 & -0.73 & -0.53 & -0.92 & -0.57 & 1 & \\
\hline $\mathrm{Na}$ & 0.96 & 0.98 & 0.98 & -0.85 & 0.91 & -0.91 & -0.23 & -0.75 & -0.28 & 0.95 & 1 \\
\hline
\end{tabular}


Moruf, R. O., Akinwunmi, M. F., Lawal-Are, A. O. (2021). Chemometric estimation of captured Farfantepenaeus notialis, Pérez-Farfante 1967 (Crustacea: Penaeidae). Acta Sci. Pol. Technol. Aliment., 20(3), 291-299. http://dx.doi.org/10.17306/J.AFS.2021.0947

Table 7. Correlation coefficient among the proximate and mineral compositions of the flesh of Farfantepenaeus notialis

\begin{tabular}{|c|c|c|c|c|c|c|c|c|c|c|c|}
\hline & Moisture & Protein & Fat & Fibre & Ash & $\mathrm{CHO}$ & $\mathrm{Ca}$ & $\mathrm{Mg}$ & K & $\mathrm{P}$ & $\mathrm{Na}$ \\
\hline Moisture & 1 & & & & & & & & & & \\
\hline Protein & 0.99 & 1 & & & & & & & & & \\
\hline Fat & 0.99 & 0.99 & 1 & & & & & & & & \\
\hline Fibre & -1 & -0.99 & -0.98 & 1 & & & & & & & \\
\hline Ash & 0.5 & 0.57 & 0.62 & -0.5 & 1 & & & & & & \\
\hline NFE & 0.99 & 0.98 & 0.96 & -0.99 & 0.40 & 1 & & & & & \\
\hline $\mathrm{Ca}$ & -0.95 & -0.97 & -0.99 & 0.95 & -0.74 & -0.92 & 1 & & & & \\
\hline $\mathrm{Mg}$ & -0.38 & -0.31 & -0.24 & 0.38 & 0.61 & -0.48 & 0.09 & 1 & & & \\
\hline K & -0.93 & -0.95 & -0.98 & 0.93 & -0.78 & -0.89 & 0.99 & 0.02 & 1 & & \\
\hline $\mathrm{P}$ & -0.99 & -0.99 & -0.99 & 0.99 & -0.55 & -0.99 & 0.97 & 0.33 & 0.95 & 1 & \\
\hline $\mathrm{Na}$ & -0.10 & -0.17 & -0.25 & 0.10 & -0.91 & -0.01 & 0.39 & -0.88 & 0.45 & 0.15 & 1 \\
\hline
\end{tabular}

\section{Functional differentiation}

The results shown in Figure 2 reveal better functional properties (with the exception of swelling power) in the exoskeleton sample of $F$. notialis, while the flesh sample had a significantly $(P<0.05)$ higher percentage of swelling power $(111.9 \pm 0.01 \%)$. This value is lower than the $277.30 \pm 0.44-310.30 \pm 6.14 \%$ swelling power reported for berried smooth swim crab (Lawal-Are et al., 2020). The disparity in absorption capacities is a function of the quantity of non-polar amino acids in the side chain and structure of the proteins (Lone et al., 2015). Water absorbing capacity reveals the degree of

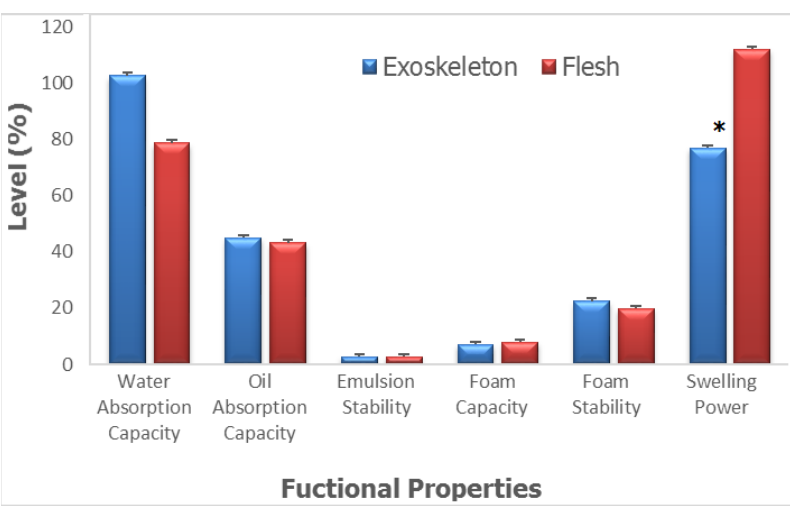

Fig. 2. Functional attributes of Farfantepenaeus notialis denaturation of the protein while oil absorbing capacity acts as a taste retainer and improves the mouthfeel of food.

Foamability is an essential property of food in which proteins form a versatile cohesive film to capture air bubbles (Lone et al., 2015). In this study, the foaming capacity and stability are in close agreement with the foaming capacity of Sepia officinalis (7.2\%) (Lawal-Are et al., 2018b) and foaming stability of $\mathrm{Pe}$ naeus notialis (25.0\%) (Adeyeye and Adamu, 2010). In the present study, F. notialis had an emulsion stability similar to the value of $5.0 \%$ reported for $P$. notialis, and this value suggests that penaeid shrimp could be used in the production of sausages, soups and cakes as an additive for the stabilization of fat emulsions. (Adeyeye and Adamu, 2010; Lawal-Are et al., 2020).

\section{CONCLUSION}

The proximate parameters of Farfantepenaeus notialis are better concentrated in the flesh than in the exoskeleton. The exoskeleton sample, however, had a higher mineral content, contributing significantly to the nutritional qualities of the shrimp. The high range values of the coefficient of variation percentage indicate heterogeneous relationships between the exoskeleton and flesh proximate compositions of $F$. notialis. 
The exoskeleton sample had better functional properties, but the flesh sample was higher in swelling strength. As the content of fibre is very low, the shrimp may be ideal as a weaning food for children.

\section{REFERENCES}

Adeyeye, E. I., Adamu, A. S. (2010). Proximate, mineral and amino acid composition and functional properties of pink shrimp, Penaeus notialis whole body. J. Appl. Environ. Sci., 6(2), 124-133.

Afolayan, O. A., Moruf, R. O., Lawal-Are, A. O. (2020). Bacterial contamination and heavy metal residues in frozen shellfish retailed within Lagos Metropolis, Nigeria. Sci. World J., 15(1), 11-14.

Akinjogunla, V. F., Moruf, R. O. (2018). The ecology and growth biology of Farfantepenaeus notialis (Pérez-Farfante, 1967) from an open tidal estuary in Nigeria. Nigerian J. Fish., 15(1), 1326-1335.

Akinwunmi, M. F. (2016). Growth pattern of Macrobrachium vollenhovenii fed with varied crude protein levels of purified and local diets. Nigerian J. Fish., 13(1\&2), 1051-1057.

Akinwunmi, M. F., Lawal-Are, A. O. (2019). Molecular identification of strains of Caridean species in a tropical lagoons of South-Western Nigeria. J. Sci. Res., 11(1), 111-120. http://dx.doi.org/10.3329/jsr.v11i1.37282

Anwarul, I., Shuvagato, M., Shuva, B., Shanzida, I., Mohajira, B. (2017). A comparative analysis of the proximate composition of wild and cultured prawn ( $\mathrm{Ma}$ crobrachium rosenbergii) and shrimp (Penaeus monodon). Int. J. Fish. Aquatic Stud., 5(4), 59-62.

AOAC (2006). Official methods of analysis, 18th ed. Washington, DC: Association of Official Analytical Chemists.

Banu, S. K., Hareesh, K., Reddy, M. S. (2016). Evaluation of nutritional status of penaeid prawns through proximate composition studies. Int. J. Fish. Aquatic Stud., 4(1), 13-19.

Brishti, F. H., Zarei, M., Muhammad, S. K. S., Ismail-Futry, M. R., Shukri, R. (2017). Evaluation of the functional properties of mung bean protein isolate for development of textured vegetable protein. Int. Food Res. J., 24(4), $1595-1605$.

FAO (2020). The state of world fisheries and aquaculture 2020. Sustainability in action. Rome.

Hatcock, J. N. (1985). Quantitative evaluation of vitamin safety. Pharm. Times, 51, 104-113.

Khalili, T. S., Sampels, S. (2018). Nutritional value of fish: lipids, proteins, vitamins, and minerals. Rev. Fish. Sci.
Aquacult., 26(2), 243-253. https://doi.org/10.1080/2330 8249.2017.1399104

Lawal-Are, A. O., Moruf, R. O., Ojeah, F. L., Taiwo, L. O., Aligbeh, O. E. (2021). Weight yield factor, chemical composition and energy value in three imported shellfish species in Nigeria. Nig. J. Anim. Prod., 48(3), 63-70.

Lawal-Are, A. O., Moruf, R. O., Sanni, M. A., Chukwujindu, C. M. (2020). Food properties of minced and whole jumbo lump of the smooth swim crab, Portunus validus (Herklot, 1851). J. Sci. Res. Develop., 19(1), 126-137.

Lawal-Are, A. O., Moruf, R. O., Afolayan, O. A. (2018a). Proximate composition, mineral profile and cholesterol level in whole and fillet of the Guinean Mantis Shrimp, Squilla aculeata calmani (Holthuis, 1959) (Crustacea: Stomatopoda). Albanian J. Agric. Sci., 17(3), 160-165.

Lawal-Are, A. O., Moruf, R. O., Junaid, D. A., Oke, M. O. (2018b). Chemical bio-compounds and functional properties of raw and processed cuttlefish, Sepia officinalis (Mollusca: Cephalopoda). Food Environ. Safety, 17(3), 332-340.

Lone, D. A., Wani, N. A., Wani, I. A., Masoodi, F. A. (2015). Physico-chemical and functional properties of rainbow trout fish protein. Int. Food Res. J., 22(3), 1112-1116.

Manan, H., Ikhwanuddin, M. (2020). Triploid induction in penaeid shrimps aquaculture: a review. Rev. Aquacult., 13, 619-631.

McDonough, A. A., Veiras, L. C., Guevara, C. A., Ralph, D. (2017). Cardiovascular benefits associated with higher dietary $\mathrm{K}+\mathrm{vs}$. lower dietary $\mathrm{Na}+$ : evidence from population and mechanistic studies. Am. J. Physiol.-Endocrinol. Metab., 312, 348-356.

Mili, S., Bouriga, N., Ennouri, R., Jarboui, O., Missaoui, H. (2013). Food and biochemical composition of the spottail mantis shrimp Squilla mantis caught in three Tunisian Gulfs: Tunis, Hammamet and Gabes. Cah. Biol. Mar., 54, 271-280.

Moruf, R. O., Afolayan, O. A., Taiwo, M. A., Ogunbambo, M. M. (2021a). Estimation of nutritional energy values, mineral ratio and mineral safety index in the Royal Spiny Lobster, Panulirus regius (De Brito Capello, 1864). Croat. J. Food Sci. Technol., 13(1), 105-110.

Moruf, R. O., Durojaiye, A. F., Taiwo, M. A. (2021b). Comparison between the proximate and mineral compositions of feral and cultured gecarcinid crab. $46^{\text {th }}$ Annual Conference, Nigerian Society for Animal Production. Dutsin-Ma 2021.

Moruf, R. O., Taiwo, M. A., Adebayo, Q. (2021c). Nutritional and functional attributes of raw and grilled crabmeat. Agric. Sci. Technol., 13(1), 83-90. https://doi. org/10.15547/ast.2021.01.016 
Moruf, R. O., Akinwunmi, M. F., Lawal-Are, A. O. (2021). Chemometric estimation of captured Farfantepenaeus notialis, Pérez-Farfante 1967 (Crustacea: Penaeidae). Acta Sci. Pol. Technol. Aliment., 20(3), 291-299. http://dx.doi.org/10.17306/J.AFS.2021.0947

Moruf, R. O., Akinjogunla, V. F. (2019). Concentration of heavy metals in sediment of two interconnecting brackish/freshwater lagoons and the bioaccumulation in the crustacean, Farfantepenaeus notialis (Pérez-Farfante, 1967). J. Fish. Environ., 43(3), 55-62.

Moruf, R. O., Lawal-Are, A. O. (2019). Protein, amino acid and fatty acid profiles of two edible crabs of Lagos coast, Nigeria. J. Bangladesh Agric. Univ., 17(3), 396401. https://doi.org/10.3329/jbau.v17i3.43222

Moruf, R. O., Saba, A. O., Chukwu-Osazuwa, J., Elegbede, I. O. (2019). Seasonal variation in macro-micronutrient compositions of the flesh and shell of the portunid crab, Callinectes amnicola (De Rochebrune, 1883) from the coastal waters of Southwest Nigeria. Agricultura, 102(1-2), 200-209.

Moruf, R. O., Akinjogunla, V. F. (2018). Photometric determination of macro-micro minerals in the West African Mud Creeper, Tympanotonus fuscatus var radula (Linnaeus, 1758). J. Exp. Res., 6(3), 35-40.

Moruf, R. O., Lawal-Are, A. O. (2017). Size composition, Growth pattern and Condition factor of two Portunid crabs, Callinectes amnicola (De Rochebrune) and Portunus validus (Herklots) off Lagos coast, Nigeria. Nigerian J. Fish. Aquacult., 5(1), 15-21.
Nwabueze, C. J., Sogbanmu, T. O., Ugwumba, A. A. A. (2020). Physicochemical characteristics, animal species diversity and oxidative stress responses in dominant fish from an impacted site on the Lagos Lagoon, Nigeria. Ife J. Sci., 22(2), 81-93. https://dx.doi.org/10.4314/ijs. v22i 2.8

Oluwole, G., Moruf, R. O., Lawal-Are, A. O. (2020). Meat quality of Land Crab, Cardiosoma armatum (Herklots, 1851) fattened with trash fish and formulated diet. J. Sci. Res., 12(3), 371-377. http://dx.doi.org/10.3329/jsr. v12i3. 44210

Santoso, J., Yoshie-Stark, Y., Suzuki, T. (2006). Comparative content of minerals and dietary fibers in several tropical seaweeds. Bull. Aquatic Prod. Technol., 9(1), 1-11. http://doi.org/10.17844/jphpi.v9i1.995

Souissi, N., Bougatef, A., Triki-Ellouz, Y., Nasri, M. (2007). Biochemical and functional properties of sardinella (Sardinella aurita) by-product hydrolysates. Food Technol. Biotechnol., 45(2), 187-194.

Watts, D. L. (2010). HTMA mineral ratios: A brief discussion of their clinical importance. Trace Elements Newsletter, 21(1), 1-3. 
